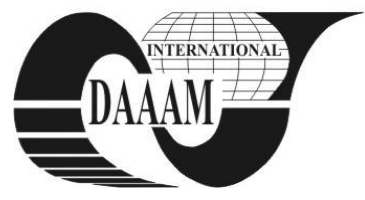

\title{
RESEARCH CONCERNING THE EVOLUTION OF HEAVY METALS CONTENT IN THE FRESH AND METAL CAN PRESERVED VEGETABLES (TOMATOES)
}

\author{
BUCULEI, A[melia]; POROCH - SERITAN, M[aria]; PSIBILSCHI, A[lina] - M[ihaela] \& \\ REBENCIUC, I[oana]
}

\begin{abstract}
The research was carried out with the following purpose:- to determine the level of heavy metal accumulation in the tissues of certain vegetable species taken from polluted industrial areas and the degree to which their content is modified during technological processing operations;- to study the possibilities in which fresh vegetable species with a high content of heavy metals (an exceed of LMA) can be used in the canning industry, in conditions assuring full safety for consumers. Research findings have revealed that tomato juice content of heavy metals is significantly lower compared to that of fresh tomatoes (especially in the case of lead and cadmium).
\end{abstract} Key words: metals, tomato, diffusion, processing, conservation

\section{INTRODUCTION}

Heavy metals are stable chemical elements that do not go through thermal or chemical depreciation, but can migrate in food products according to their molecular system within the vegetal tissue.

The environment contamination and heavy metals exposure $(\mathrm{Cd}$ and $\mathrm{Pb})$ is a severe problem gaining magnitude all over the world. The human organism's exposure to heavy metals has dramatically increased in the past 50 years as a consequence to the exponential development of using heavy metals in the industrial processes.

The consumption of tomatoes is currently considered as a nutritional indicator of good dietary habit and healthy life style. This fruit has undoubtedly assumed the status of a food with functional properties, considering the overwhelming epidemiological evidence for its capacity to reduce the risk of certain types of cancers. Due to the importance of trace elements on human metabolism, their analysis is an important part of public health studies (Arslan \& Gizir, 2006; Colak et. al. 2005; Pourreza \& Ghanemi, 2006).

Directly, the main sources of heavy metal ions are foods and water, and indirectly industrial activities and traffic in the investigated area etc. (Saracoglu et al. 2004; Narin et al., 2005). The ingestion of food is an obvious means of exposure to metals, not only because many metals are natural components of foodstuffs, but also because of environmental contamination and contamination during processing. Heavy metal levels of various vegetables samples have been widely reported in the literature (Tuzen \& Soylak, 2006). However, trace metal contents in canned foods produced in Romania is very limited. Canned foods are a popular food source in Romania, like other countries around world.

\section{MATERIALS AND METHODS}

The analysis was performed concerning heavy metals content $(\mathrm{Cd}, \mathrm{Pb}, \mathrm{Zn}, \mathrm{Cu})$ in the tomatoes (Lycopersicum esculentum) cultivated in three different areas in Romania with various degrees of pollution (I South-East Area, II North-East Area, III North-West Area). Heavy metals content was studied for different parts of the plant (root, strain, leaves and fruit). The tomatoes were subdued to specific technological operations of obtaining canned products (tomato juice and tomato paste) and the heavy metals content in the tomato juice and residue was determined. In order to study the evolution of heavy metals content in the canned tomato paste in metallic cans during the storage period, the analysis was performed 6 and 12 months after packaging.

The determination of heavy metals content was done by atomic absorption spectrophotometry (there were used AAnalyst 400 spectrophotometers with flame, air and acetylene absorption, respectively an AAnalyst 600 spectrophotometer with graphite oven) using the following characteristic wave lengths: $\lambda_{\mathrm{Cu}}=324.8 \mathrm{~nm}, \lambda_{\mathrm{Pb}}=217.0 \mathrm{~nm}, \lambda_{\mathrm{Cd}}=229.0 \mathrm{~nm}, \lambda_{\mathrm{Zn}}=$ $214.0 \mathrm{~nm}$. The samples were mineralized according to STAS 5954/1-86 (calcination at $450-500^{\circ} \mathrm{C}$ and resulted ash dissolution with hydrochloric diluted acid).

\section{RESULTS AND DISCUSSION}

From figure 1 we can observe that the highest accumulation level for the four metals takes place in the leaves of the studied plant. The heavy metals accumulation level in the different anatomic parts of the plant presents the following decreasing variation: leaves $>$ strain $>$ root $>$ fruits. In the case of tomatoes the heavy metals content $(\mathrm{Pb}, \mathrm{Cd}, \mathrm{Zn}, \mathrm{Cu})$ of the fruits (the edible part of this species) is slightly lower in comparison with the other parts of the plant (leaves, strain, root). It was discovered the fact that the raw materials analysed present a high content of heavy metals, the majority of samples presenting a value surpassing the maximum limits admitted by law. The general limits imposed for $\mathrm{Pb}$ and $\mathrm{Cd}$ are established by the no. 1881/2006/CE Committee Regulation and on the national level by no. 351/2007 Order.

The phases of the technological process of tomatoes processing in which the microelements' composition (including heavy metals) can be modified are the following: washing, scalding in water of $95^{\circ} \mathrm{C}$, extraction in pasatrice, obtaining the raw juice and its concentration. During the scalding operation the diffusion takes place in the scalding environment in variable concentrations of mineral elements including heavy metals.

The juice and residue (covers and seeds) resulting from the obtainment of tomato juice were analysed for the following heavy metals content: $\mathrm{Pb}, \mathrm{Cd}, \mathrm{Cu}, \mathrm{Zn}$.

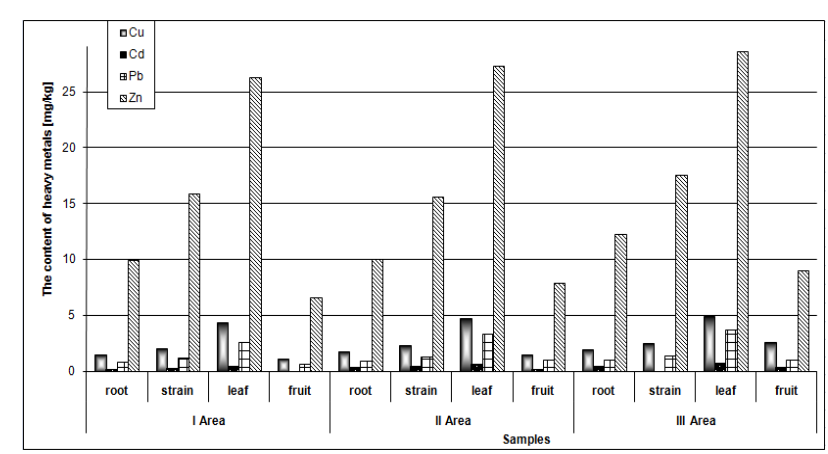

Fig.1. The heavy metals content in the different parts of the tomato plant 
The analysis of figure 2 illustrates that heavy metals content of tomato juice is significantly lower than that of fresh tomatoes (Figure 1). The most significant decreases ( $\mathrm{Pb}$ and $\mathrm{Cd}$ ) can be explained by the diffusion of these potentially toxic metals from the vegetal tissue in the scalding environment. Thus, in the case of tomato juice the $\mathrm{Pb}$ content was of cca. 1.6 times lower than in the case of fresh tomatoes while the $\mathrm{Cd}$ content was cca. 3.6 times lower. In the case of $\mathrm{Cu}$ and $\mathrm{Zn}$ the decreasement was of cca. 1.5 times lower than the fresh tomatoes. The scalding operation facilitates the reduction of heavy metals content through environment diffusion due to objective issues such as the excessive soaking of the texture (which cannot surpass 2 - 3 minutes) that results in a loss of nutrients: glucids, vitamins, mineral elements.

A special attention to $\mathrm{Pb}$ is needed, for which the limit must not overpass the actual value $(0.2 \mathrm{ppm})$ imposed by the no. 1881/2006/CE Committee Regulation and on the national level by no. 351/2007 Order.

Concurrently, the residue obtained from tomato juice extraction exhibited a high content of heavy metals. After sterilizing through solubilisation and diffusion, a different ratio of heavy metals content within the vegetal tissue can be found in the covering liquid in the cans.

This study concerning the heavy metals content of metallic canned tomatoes during their storage period was carried out after 24 hours from pasteurization (considered the reference time for the determinations) and after 6 , respectively 12 months of storage. There were taken 5 samples from each product and the content was homogenized, mineralized by calcination and analyzed by atomic absorption spectrometry.

The results obtained from the completed analysis are shown in figure 3. They illustrate that the $\mathrm{Pb}$ and $\mathrm{Cd}$ heavy metals are to be found in larger quantities once the storage time increases (due to the contact between the product and the metallic can).

Thus after 12 months of storage:

- in the case of tomato juice the levels of growth are of cca. 5.5 times for $\mathrm{Cu}$, of cca. 14 times for $\mathrm{Pb}$, cca. 6.5 times for $\mathrm{Fe}$ and of cca. 39 times for $\mathrm{Sn}$;

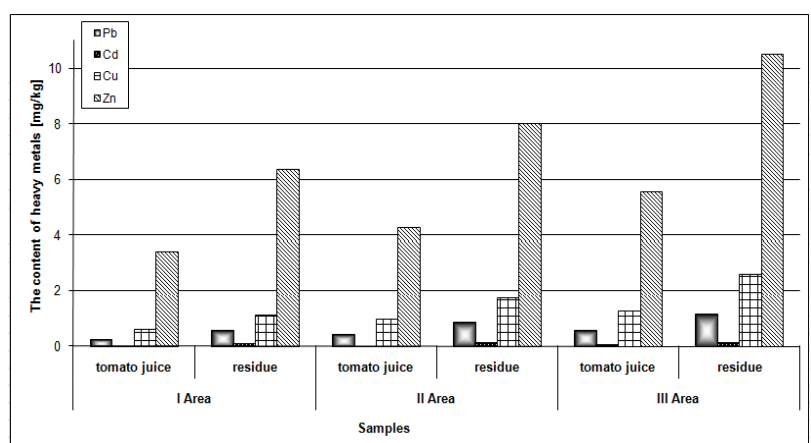

Fig. 2. The heavy metals content of the residue and raw tomato juice

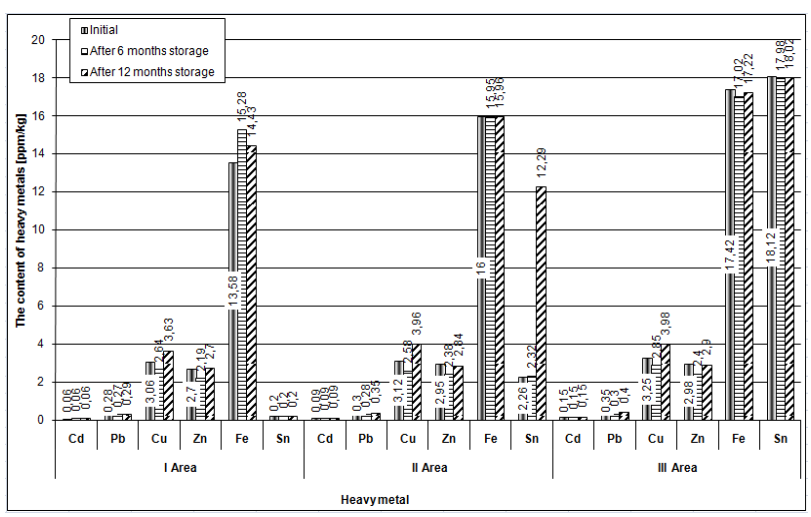

Fig. 3. The evolution of heavy metals content at the „Tomato paste" cans after different periods of storage
- in the case of tomato paste the levels of growth are of cca. 2 times for $\mathrm{Cu}$, cca. 10 times for $\mathrm{Pb}$, cca. 2.5 times for $\mathrm{Fe}$ and of cca. 27 times for $\mathrm{Sn}$;

The relatively fast development in the case of most of the studied metals (fact displayed by the graphics) underline the necessity of a control upon the contamination level with these elements both for the end of manufacturing, storage inception, delivery to the beneficiaries (different stores) as well as for the case of prolonged storage periods.

\section{CONCLUSION}

After the tomatoes' scalding and tomato juice extraction significant diminutions were registered for $\mathrm{Pb}$ and $\mathrm{Cd}$ content. Thus in the case of the tomato juice the $\mathrm{Pb}$ content was of cca. 1.6 times lower than for the fresh tomatoes while the $\mathrm{Cd}$ content was cca. 3.6 lower. In the case of $\mathrm{Cu}$ and $\mathrm{Zn}$ the diminutions were of cca. 1.5 times in comparison with the raw stuff. In the case of $\mathrm{Fe}$, even though there are no maximum admitted limits, the increase of concentration in the finished products affects their organoleptic properties. The concentration of raw tomato juice needed to obtain the tomato paste determined an increase of heavy metals content in addition to the increase of the nutrient substances content. In the situation in which the tomato juice and the tomato paste are canned in metallic cans it is necessary to determine the heavy metals content not only at the end of the manufacturing process but also periodically during storage. The finished products made from vegetables harvested across heavy metals polluted areas surpass the maximum imposed limits for the heavy metals content in different ways $(\mathrm{Pb}, \mathrm{Cd}, \mathrm{Cu}, \mathrm{Zn})$. The tomato juice and tomato paste exceed the LMA for the Cd content. Even though thermal processing treatments (washing and scalding) determine diminutions in heavy metals contents, the raw materials taken from heavily polluted areas (exceeding by several times the admitted maximum limits of heavy metals content) do not always permit the obtainment of finished products that are in accordance with the OMS regulations and prove no risks for the consumers health. Further investigations aim to identify heavy metals to get a perspective based on their bioavailability in food plant tissues, and after the process is of general interest in order to ensure food safety.

\section{REFERENCES}

Arslan, H.; \& Gizir, A.M. (2006). Heavy-metal content of roadside soil in Mersin, Turkey. Fresenius Environmental Bulletin, 15(1), 15-20, ISSN: 1018-4619

Colak, H.; Soylak, M.; \& Turkoglu, O. (2005). Determination of trace metal content of various herbal and fruit teas produced and marketed in Turkey. Trace Elements and Electrolytes, 22(3), 192-195, ISSN 0946-2104

Narin, I.; Tuzen, M.; Sari, H. \& Soylak, M. (2005). Heavy metal content of potato and corn chips from Turkey. Bulletin of Environmental Contamination and Toxicology, 74, 1072-1077, ISSN: 1432-0800

Pourreza, N. \& Ghanemi, K. (2006). Determination of copper by flame atomic absorption spectrometry after solid-phase extraction. Spectroscopy Letters, 39, 127-134, ISSN: 15322289

Saracoglu, S.; Tuzen, M.; Mendil, D.; Soylak, M.; Elci, L. \& Dogan, M. (2004). Heavy metals content of hard biscuits produced in Turkey. Bulletin of Environmental Contamination and Toxicology, 73, 264-269, ISSN: 14320800

Tuzen, M. \& Soylak, M., (2006), Evaluation of trace element contents in canned foods marketed from Turkey, Food Chemistry, 102 (2007) 1089-1095, ISSN: 0308-8146

***Regulamentul Comisiei nr. 1881/2006/CE si pe plan national de Ordinul nr. 351/2007 